\title{
Pendampingan Diversifikasi Hasil Pertanian di Masa Pandemi: Strategi Ketahanan Pangan Masyarakat di Kawasan Urutsewu, Kebumen
}

\author{
Mila Karmilah $^{1}$, Eppy Yuliani ${ }^{2}$, Andre Sugiyono ${ }^{3}$ \\ ${ }^{1,2}$, Program Studi Perencanaan Wilayah dan Kota/Fakultas Teknik, Universitas Islam Sultan \\ Agung \\ ${ }^{3}$ Fakutas Teknik Industri, Universitas Islam Sultan Agung \\ E-mail: ${ }^{1}$ mila.k@unissula.ac.id, ${ }^{2}$ epp.yul@gmail.com, ${ }^{3}$ andre@unissula.ac.id
}

\begin{abstract}
Abstrak
Keberadaan Pandemi saat ini telah membuat ketahanan masyarakay menjadi menurun, bukan hanya terkait dengan kesehatan, namun juga diperparah dengan menurunnya distribusi hasil pertanian diakibatkan adanya pemberlakuan pembatasan berskala besar hampir di semua wilayah. Kondisi ini tentunya juga berdampak pada perekonomian masyarakat khususnya petani. Salah satunya yang paling terdampak adalah produk hasil pertanian, dikarenakan adanya pembatasan. Kawasan Urutsewu Kabupaten Kebumen adalah salah satu lokasi yang pada saat ini mengalami panen raya sehingga banyak hasil panen toidak dapat dipasarkan diantaranya adalah singkong, jagung, sayur mayur dan buah-buahan. Berdasarkan permasalahan tersebut maka kegiatan pengabdian ini berusaha membantu masyarakat didalam melakukan diversifikasi produk pertanian serta membantu memasarkan produk melalui marketplace. Potensi yang dimiliki oleh kawasan urutsewu adalah sudah terbentuk kelompok yang peduli terhadap potensi yang dimiliki. Kelompok Kadang Tani Milenial ini yang menjadi sasaran jangka pendek dalam membantu masyarakat melakukan diversifikasi hasil pertanian.
\end{abstract}

Kata kunci: (diversifikasi, pandemi covid 19, ketahanan pangan )

\begin{abstract}
Covid 19 outbreak has made the resilience of the community decrease, not only related to health, but also exacerbated by the decline in the distribution of agricultural products due to the imposition of large-scale restrictions in almost all regions. This condition of course has an impact on the economy of the community, especially farmers. One of the most affected is agricultural products, due to restrictions. Urutsewu area of Kebumen Regency is one of the locations that is currently experiencing major harvests so that many crops cannot be distributed including cassava, corn, vegetables and fruits. Based on these problems, this service activity tries to help the community diversify agricultural products and help market products through the marketplace. The potential of the Urutsewu area is that a group has been formed that cares about its potential. The Kadang Tani Milenial Group is a short-term target in helping communities diversify their agricultural products
\end{abstract}

Key word: diversification, covid-19 outbreak, food security

\section{PENDAHULUAN}

Pandemi Covid-19 tidak hanya menghancurkan daya tahan fisik manusia. Penyebarannya yang cepat dan luas telah menghancurkan pula daya tahan ekonomi masyarakat. Penularannya virus yang terjadi lewat interaksi orang per orang dan dalam kerumunan membuat model pengantisipasian Covid-19 secara langsung menghancurkan perekonomian masyarakat 
(siaran pers Kobar, 3/2020). Dengan dikeluarkannya peraturan menteri kesehatan No 9 tahun 2020 tentang pembatasan sosial berskala besar (PSBB) serta keputusan Kepala Badan Nasional Penanggulan Bencana (BNPB) no 9 A tahun 2020 tentang penetapan status keadaan tertentu darurat bencana wabah penyakit akibat virus Corona di Indonesia [1] Rezeky. AA, 2020 dan no 13 A tahun 2020 tentang perpanjangan status keadaan tertentu darurat bencana wabah penyakit akibat virus Corona di Indonesia [2] Elias. Z, 2020. Dampak dari keluarnya keputusan tersebut mengakibatkan terputusnya rantai distribusi pasokan bahan makanan dan rantai produksi bahan makanan. Penyebab dari potensi terganggunya produksi adalah karena terganggunya rantai distribusi. Harga-harga anjlok adanya pembatasan interaksi antara produsen dengan distributor dan konsumen, permainan tengkulak, terhambatnya sarana transportasi, dan ketidakpastian/ketiadaan kebijakan negara soal protokol distribusi barang yang adaptif terhadap pandemic Covid-19. Sementara di tingkatan konsumen, baik yang berbasis di pedesaan maupun perkotaan, sering mengalami kelangkaan terhadap barang- barang tertentu karena putusnya rantai distribusi barang tersebut.

Covid-19 merupakan penyakit menular yang berpotensi menimbulkan kedaruratan kesehatan masyarakat. Oleh sebab itu, tindakan pencegahan terhadap jenis penyakit menular tersebut wajib dilakukan secepat mungkin [1]. Pemunculan wabah ini tidak serta merta namun sudah berlangsung puluhan tahun dan disampaikan bahwa penyebab karena adanya gangguan keseimbangan ekologi. Baik COVID 19 maupun virus corona penyebab SARS dan MERS masih tergolong dalam genus Beta Corona dalam familia Corona Viridae. Ketiga jenis beta corona virus ini diketahui punya banyak inang yang mirip, baik inang alami pada satwa liar seperti kelelawar dan binatang pengerat (rodentia) maupun hewan ternak hingga inang fatal seperti manusia [2].

Kemunculan virus ini sudah diramalkan oleh salah seorang penulis sains kedokteran Newsday New York Laurie Garret. Dalam salah satu bab pada buku yang berjudul AIDS in The Words disampaikan bahwa pada tahun 2000 an akan muncul berbagai jenis virus yang akan membahayakan manusia. Hal ini disebabkan terjadinya kemerosotan lingkungan hidup akibat meningkatnya populasi manusia, ketercerabutan manusia dari permukiman aslinya, urbanisasi besar-besaran ke kota.

Menurut [3] menyatakan bahwa (Coronavirus Disease 2019 (COVID-19) adalah penyakit jenis baru yang belum pernah diidentifikasi sebelumnya pada manusia. Virus penyebab COVID-19 ini dinamakan Sars-CoV-2. Virus corona adalah zoonosis (ditularkan antara hewan dan manusia). Orang yang paling berisiko tertular penyakit ini adalah orang yang kontak erat dengan pasien COVID-19 termasuk yang merawat pasien COVID-19. Tanda dan gejala umum infeksi covid-19 termasuk gejala gangguan pernapasan akut seperti demam, batuk, dan sesak napas. Masa inkubasi rata-rata adalah 5 - 6 hari dengan masa inkubasi demam, batuk, dan sesak napas. Pada kasus yang parah, covid-19 dapat menyebabkan pneumonia, sindrom pernapasan akut, gagal ginjal, dan bahkan kematian. Sedangkan Menurut [4] COVID-19 merupakan penyakit menular yang disebabkan oleh virus bernama SARS-COV-2, atau seringkali disebut Virus Corona. Virus Corona sendiri merupakan keluarga virus yang sangat besar. Infeksi terjadi pada hewan dan manusia (Tim Penulis Pemerintah Jawa Timur, 2019). Pada manusia biasanya menyebabkan penyakit infeksi saluran pernapasan, mulai flu biasa hingga penyakit yang serius seperti Middle East Respiratory Syndrome (MERS) dan Sindrom Pernapasan Akut Berat/Severe Acute Respiratory Syndrome (SARS). Penyakit ini menyebar melalui tetesan pernapasan dari batuk dan bersin. Virus ini dapat tetap bertahan hingga tiga hari dengan plastik dan stainless steel SARS CoV-2 dapat bertahan hingga tiga hari, atau dalam aerosol selama tiga jam. Virus ini juga telah ditemukan di feses, tetapi hingga Maret 2020 tidak diketahui apakah penularan melalui feses mungkin, dan risikonya diperkirakan rendah [5]

Menurut RPJMN 2015-2019 terdapat 5 (lima) strategi dalam rangkan menjaga ketahanan pangan nasional dan salah satunya yang terkait dengan kondisi pandemic Covid 19 adalah pada strategi (1) yaitu peningkatan ketersediaan pangan melalui penguatan kapasitas produksi dalam negeri, yang meliputi komoditas padi, jagung, kedelai, daging, gula, cabai dan bawang merah; (2) peningkatan kualitas distribusi pangan dan aksesibilitas masyarakat terhadap 
pangan; dan strategi ke (4) Mitigasi gangguan terhadap ketahanan pangan dilakukan terutama mengantisipasi bencana alam dan dampak perubahan iklim dan serangan organisme pengganggu tanaman dan penyakit hewan [6]. Oleh karenanya menjaga ketahanan pangan dan peningkatan akses masyarakat serta mitigasi akibat dari wabah (pandemic covid 19) menjadi hal yang penting untuk menjadi perhatian.

Ketahanan pangan mempunyai peran strategis dalam pembangunan nasional. Untuk memenuhi hal tersebut diperlukan ketersediaan pangan yang cukup setiap waktu, aman, bermutu, bergizi, dan beragam dengan harga yang terjangkau oleh daya beli masyarakat (UU No.7/1996 tentang Pangan), yang diutamakan berasal dari kemampuan sektor pertanian domestik dalam menyediakan bahan makanan yang dibutuhkan oleh masyarakat (PP No.68/2002 tentang Ketahanan Pangan) dalam [7]

Ketahanan pangan merupakan salah satu masalah yang terdampak dari adanya pandemi ini, sehingga perbincangan ketahanan pangan menjadi topik yang menguat, hal ini terjadi dikarenakan masalah Kesehatan dan social yang merupakan masalah yang mengalami dampak paling awal telah dapat ditangani, namun masalah ketahanan pangan seringkali terabaikan tidak terkecuali yang terjadi di Jawa Tengah. Salah satu kabupaten di Jawa Tengah yang juga mengalami perubahan dan terdampak dari adanya pandemic ini adalah Kabupaten Kebumen. Di awal pandemic kabupaten Kebumen sedang mengalami panen raya utama beberapa tanaman pangan seperti jagung, singkong, sayur serta buah-buahan.

Menurut [8] Dewan Riset Nasional (2006) Permasalahan pangan yang dihadapi baik secara global, nasional, maupun lokal dapat dipilah menjadi masalah produksi, distribusi, dan konsumsi. Terwujudnya kemandirian pangan, antara lain ditandai oleh indikator: (a) mantapnya ketersediaan pangan nasional, yang dicerminkan oleh impor pangan utama di bawah 10 persen dari kebutuhan pangan nasional, (b) menurunnya tingkat kerawanan pangan yang dicirikan oleh pengurangan jumlah penduduk setengahnya, yang mempunyai tingkat konsumsi pangan energi kurang dari 70 persen dari AKG (angka kecukupan gizi), (c) terpenuhinya kebutuhan pangan tingkat rumah tangga, yang direpresentasikan oleh konsumsi energi sebesar $2.000 \mathrm{kkal} / \mathrm{kap} / \mathrm{hari}$ dan konsumsi protein 52 gram/kap/hari, (d) meningkatnya keanekaragaman konsumsi pangan, dan menurunnya ketergantungan pada`satu jenis pangan tertentu pada'tingkat rumah tangga. Ketahanan pangan dihasilkan oleh suatu sistem pangan yang terdiri atas tiga subsistem, yaitu : (a) ketersediaan pangan dalam jumlah dan jenis yang cukup untuk seluruh penduduk, (b) distribusi pangan yang lancar dan merata, dan (c) konsumsi pangan setiap individu yang memenuhi kecukupan gizi dan kaidah kesehatan Deptan RI, 2006, dalam [9]

Ketahanan pangan merupakan situasi dimana setiap rumahtangga disetiap saat memiliki akses untuk memperoleh pangan yang cukup, aman, dan sehat untuk seluruh anggota keluarga. Empat komponen yang harus ada dalam ketahanan pangan yaitu, ketersediaan, aksesibilitas, keamanan, dan keberlanjutan (Vini \& Wulandari, 2008). Dalam [10]

Beberapa definisi terkait ketahanan pangan dalam sumber [11] menyatakan bahwa definisi ketahanan pangan sangat bervariasi, namun umumnya mengacu definisi dari Bank Dunia dan Maxwell dan Frankenberger yakni "akses semua orang setiap saat pada pangan yang cukup untuk hidup sehat (secure access at all times to sufficient food for a healthy life). Menurut Undang-Undang Nomor 7 tahun 1996 [12] disampaikan bahwasanya konsep pangan adalah segala sesuatu yang berasal dari hayati dan air, baik olahan maupun tidak, yang diperuntukkan sebagai makanan dan minuman sebagai bahan konsumsi manusia, termasuk bahan tambahan pangan, bahan baku pangan, dan bahan lain yang digunakan dalam proses penyiapan, pengolahan dan atau pembuatan makanan atau minuman. USAID menjelaskan bahwa akses pangan adalah kondisi ketika semua orang mempunyai akses secara fisik dan ekonomi untuk memperoleh kebutuhan konsumsinya untuk hidup sehat dan produktif. Sedangkan FAO juga menyatakan hal yang mirip dengan USAID namun disampiakan pula bahwa keluarga tidak kehilangan akses pada sumber pangan. Adapun Mercy Corps (2007) menambahkan variable lainnya selain akses pada fisik dan ekonomi adalaha akses social untuk dapat memenuhi kebutuhan pangannya. Kemudian ditambahkan oleh FIVIMS (2005) menyatakan kondisi ketika semua orang pada segala waktu secara fisik, social dan ekonomi 
memiliki akses pada pangan yang cukup, dan aman.

Berdasarkan definisi tersebut dapat ditarik kesimpulan bahwa ketahanan pangan memiliki lima unsur yang harus dipenuhi: (i) Berorientasi pada rumah tangga dan individu; (ii) Dimensi waktu setiap saat pangan tersedia dan dapat diakses; (iii) Menekankan pada akses pangan rumah tangga dan individu, baik fisik, ekonomi dan sosial; (iv) Berorientasi pada pemenuhan gizi; dan (v) Ditujukan untuk hidup sehat dan produktif [13]

\section{METODE}

Metode pelaksanaan pada kegiatan pengabdian masyarakat secara umum menggunakan Metode PAR (Participatory Action Research) dan terdapat 3 (tiga) tahapan yang akan di lakukan pada program pengembangan model ketahanan pangan dampak COVID 19

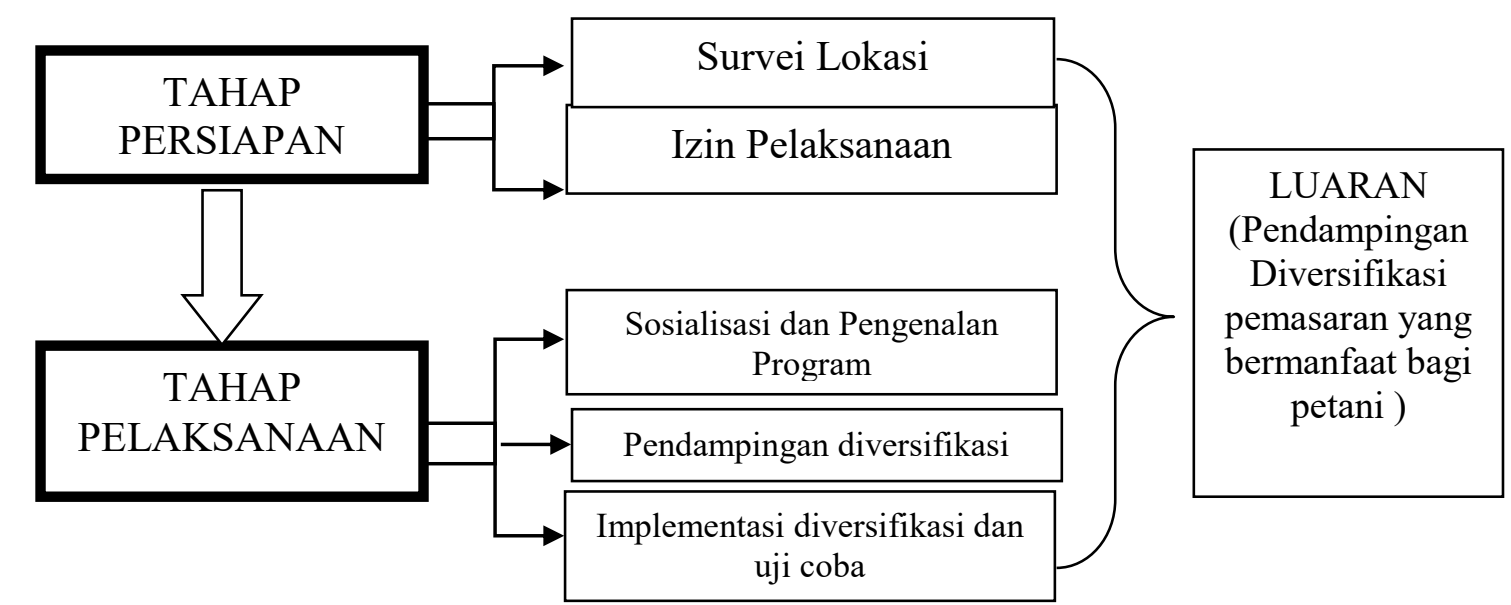

Sumber: Hasil Analisis Tim Penyusun, 2020

Gambar 1 Metode Pelaksanaan

\section{HASIL DAN PEMBAHASAN}

\subsection{Profil "Kadang Tani Milenial" Kebumen}

Adalah sebuah kelompok yang diinisiasi oleh beberapa orang yang bertujuan untuk menggabungkan atau mengumpulkan petani-petani yang berada di lingkup kawasan Karadenan untuk sama-sama dapat meningkatkan harga jual hasil panen dengan cara memodifikasi dan mentransformasi bentuk dari hasil panen tersebut menjadi produk olahan siap santap. Didirikan sejak 29 April 2020 dengan jumlah anggota awal sebanyak 15 orang, kelompok Kadang Tani Milenial ini memiliki struktur organisasi yang terdiri dari petani dan pekerja yang memiliki usaha sampingan di bidang pertanian. Adapun struktur organisasinya adalah sebagai berikut. 


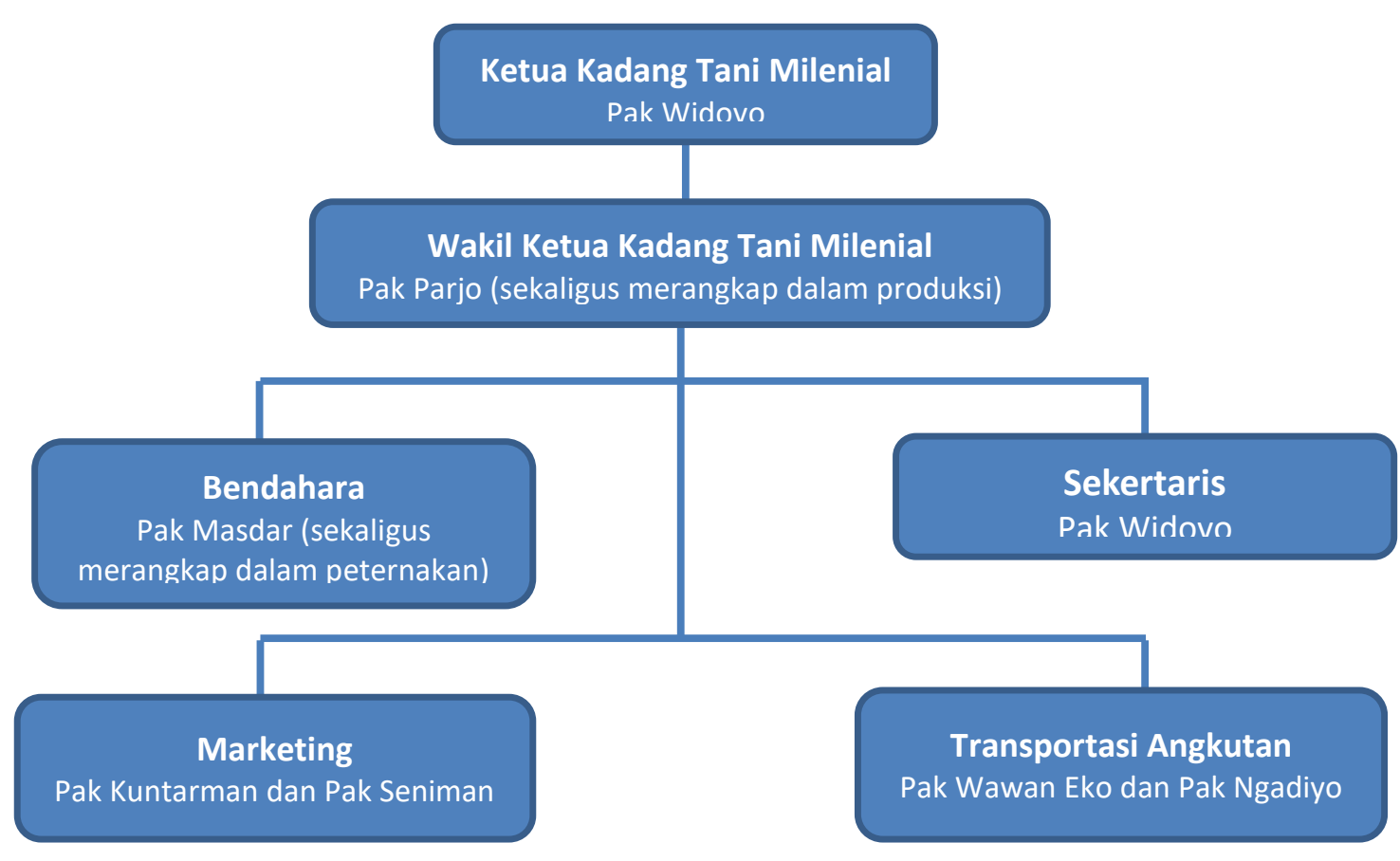

Gambar 2 Struktur Organisasi Kelompok Kadang Tani Milenial

\subsection{Pelaksanaan Pendampingan Diversifikasi hasil pertanian}

Dalam pendampingan yang dilakukan kepada kelompok Kadang Tani Milenial adalah melakukan pendampingan terkait diversifikasi hasil pertanian utamanya adalah singkong dan jagung. Saat ini produk singkong dan jagung melimpah dengan harga penjualan segar sebesar Rp 2500/kg, untuk jagung sebesar Rp 1500/kg. Target pemasaran terhadap produk olahan oyek adalah orang-orang yang terkena diabetes dimana kadar gula dalam setiap makanan yang dimakan harus dikontrol, serta orang-orang yang sedang menjalani diet dikarenakan bahan baku utama oyek adalah singkong yang dapat menjadi pengganti nasi atau produk makanan lain. Selain produk olahan bernama oyek, kelompok Kadang Tani Milenial juga berusaha untuk memasarkan madu klanceng, yakni madu yang terbuat dari lebah yang tidak menyengat sehingga memiliki cita rasa yang berbeda dari kebanyakan madu yang dijual di pasaran yang biasanya memiliki rasa manis. Madu klaceng memiliki cita rasa asam manis yang selain bagus untuk para penderita asam lambung, madu klanceng yang digadang sebagai komplementer dari oyek juga dapat memberikan imunitas lebih, terutama pada pasien-pasien covid-19 yang membutuhkan kekebalan tubuh lebih dibandingkan orang yang tidak terinfeksi covid-19 menurut orang-orang yang sudah pernah mengkonsumsi madu klanceng sebelumnya. Harga jual yang mahal juga menjadi kendala dalam sistem pemasaran karena belum menemukan pasar serta proses produksi yang cukup tinggi sehingga kelompok Kadang Tani Milenial memasarkan produk dengan sistem paket dengan tujuan agar produk-produk olahan mereka bisa terjangkau oleh semua lapisan masyarakat. Harga jual oyek masih terbilang cukup tinggi yakni Rp 18.000 untuk 250 gram sehingga masyarakat lebih memilih beras dibandingkan oyek. Selian itu, image oyek di tengah masyarakat merupakan sebuah makanan kampung yang tidak memiliki nilai jual ekonomis dan terkesan kampungan meskipun kandungan gizi yang dimiliki oleh oyek lebih baik dibandingkan dengan beras biasa. Masih banyak masyarakat yang belum teredukasi mengenai beberapa makanan pengganti beras sebagai makanan pokok sehingga oyek kurang mendapatkan perhatian, hanya beberapa saja yang mengetahui manfaat yang dihasilkan setelah mengkonsumsi oyek. Proses produksi oyek yang panjang dikarenakan pada tahap pengeringan masih menggunakan sistem yang konvensional, belum ada alat yang digunakan untuk mengeringkan oyek sehingga antar tahapan produksi tidak bisa saling menutupi karena selama proses pengeringan tidak ada oyek yang bisa dijual (produksi masih terbatas). Proses 
pengeringan masih tergantung pada panas matahari sehingga ketika musim hujan, oyek sulit untuk dikeringkan. Kelompok Kadang Tani Milenial sudah menginisiasi untuk menggunakan oven dalam proses pengeringan. Namun belum ada dana yang masuk untuk membuat atau membeli oven tersebut yang bisa mengeringkan sebanyak $30-35 \mathrm{~kg}$ dalam sekali proses pengovenan. Antara proses produksi hingga menjadi produk jadi sekitaran Rp 12.500 per produk, dengan harga bahan baku utama berkisar antara Rp 500 - Rp 2500 per kilogramnya dengan masa unduh sejak panen antara 8-12 bulan yang bisa dijadikan oyek dengan kualitas baik. Awalnya, kelompok Kadang Tani Milenial juga menggunakan jagung sebagai bahan pokok dalam pembuatan oyek, namun karena harga jual jagung yang mahal (Rp 2100/kg) dan hasil olahan yang lebih sedikit serta proses produksi yang memakan biaya lebih dibandingkan dengan bahan baku singkong, alhasil oyek yang berbahan utama jagung hanya dibuat ketika ada pesanan yang diterima.
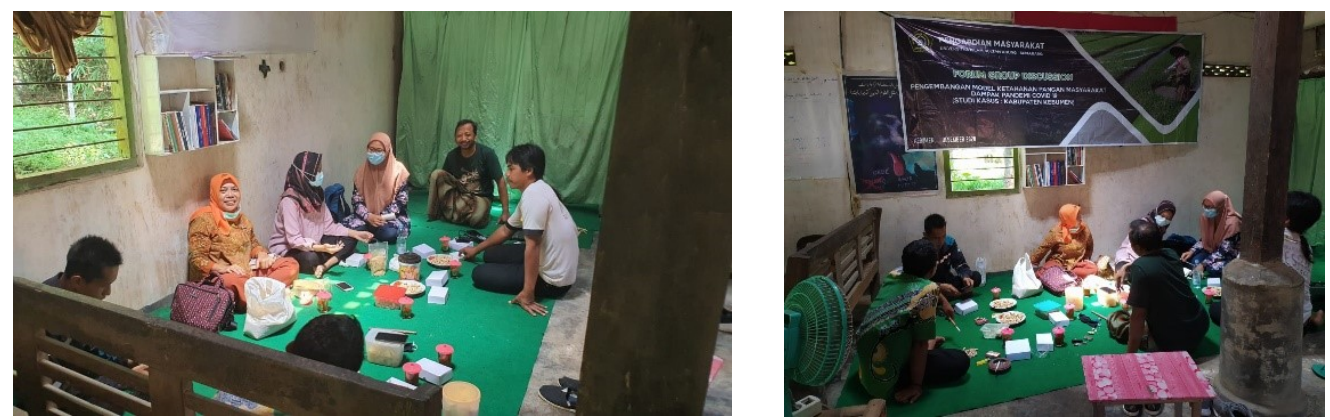

Gambar 3 Kegiatan FGD Bersama Kelompok Usaha Kadang Tani Milenial
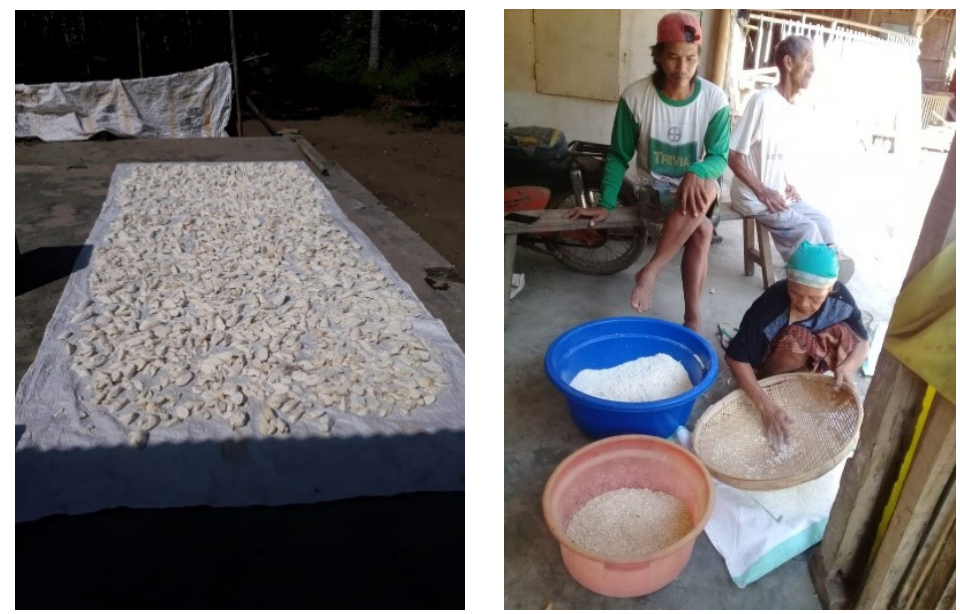

Gambar 4 Proses pembuatan oyek dan penjemuran oyek

\subsection{Pelatihan pemasaran (melalui marketplace)}

Metode pemasaran yang dilakukan oleh kelompok Kadang Tani Milenial sudah menggunakan sistem jual beli online, hanya saja karena tidak adanya informasi terkait dengan kandungan gizi pada masing-masing produk membuat konsumen menjadi ragu untuk melakukan pembelian. Disamping itu, pendeskripsian terkait dengan manfaat produk hanya sebatas dari testimoni orang-orang yang sudah mengkonsumsi produknya sehingga tidak ada bukti ilmiah terkait dengan khasiat dari masing-masing produk.

Teknik pemasaran yang kurang memadai menjadi salah satu permasalahan juga bagi perkembangan produk olahan oyek milik kelompok Kadang Tani Milenial. Selain karena kurangnya perencanaan dana, mereka kesulitan untuk mencari orang-orang yang bisa mempengaruhi (social media influencer) dan dapat membantu meningkatkan pemasaran produk olahan ini. Koneksi yang kurang juga menjadi salah satu penyebab mengapa pemasaran produk 
olahan milik kelompok Kadang Tani Milenial masih sebatas jejaring kecil yang bersifat diturunkan dari mulut ke mulut. Mereka belum mampu mengembangkan jaringan pemasaran meskipun produk-produk olahannya sudah dikonsumsi oleh beberapa konsumen yang notabene berasal dari kota-kota besar seperti Banten, Jakarta, dan Bekasi.
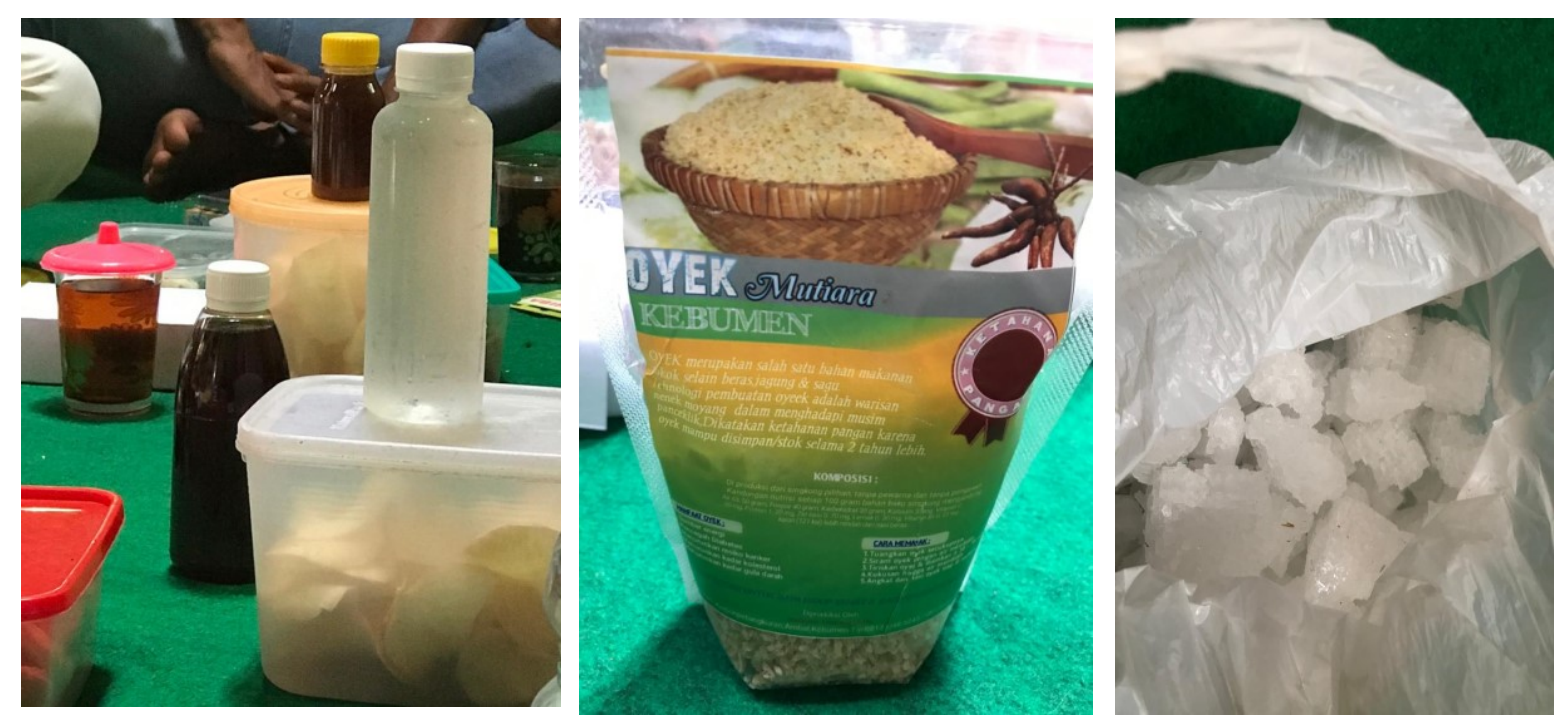

Gambar 5 Produk Paket Oyek Kelompok Kadang Tani (Sumber: dokumentasi pribadi, 2020)

Metode pemasaran yang dilakukan oleh komunitas kadang Tani Milenial adalah membuat paket penjualan seperti pada gambar 5 diatas, selain memasarkan melalui media social seperti whatsapps dan facebook, namun dengan dengan media social yang ada tersebut belum mampu memperlebar jangkauan pemasaran nasi oyek Mutiara, sehingga diadakan sosialisasi terkait market place. Memberikan sosialisasi terkait dengan teknik pemasaran (teknik marketplace) yang aplikatif dan dapat dipahami oleh seluruh anggota kelompok Kadang Tani Milenial sehingga tidak hanya 1 atau 2 orang saja yang paham mengenai trik pemasaran terhadap hasil produk olahan yang dimiliki. Pelatihan sekaligus memberdayakan sumber daya manusia yang terdapat di kelompok Kadang Tani Milenial dan nantinya diharapkan setelah pelatihan tersebut tidak hanya diaplikasikan kepada kelompok Kadang Tani Milenial, namun juga seluruh pelaku industri rumahan oyek dan produk olahan lainnya yang berada di Karadenan.

\section{KESIMPULAN DAN SARAN}

\subsection{Kesimpulan}

Beberapa produk olahan dari kelompok Kadang Tani Milenial ini memiliki banyak manfaat, terutama bagi orang-orang yang menderita diabetes atau yang sedang menjalani diet, namun karena belum adanya informasi gizi yang tertera membuat konsumen menjadi sangsi ketika melakukan pembelian. Sistem pemasaran yang masih bersifat mulut ke mulut juga menjadi salah satu penyebab mengapa produk olahan dari kelompok Kadang Tani Milenial ini belum dikenal oleh khalayak luas dikarenakan kurangnya sumber daya manusia yang difokuskan untuk menjalani sistem pemasaran karena divisi Warung Kober dibuat oleh orangorang yang masih memiliki pekerjaan utama dan Warung Kober ini hanya sebagai sampingan mereka. Selain itu, waktu produksi yang cukup lama karena teknik pengeringan masih bergantung pada ketersediaan panas matahari dan apabila oyek tidak dijemur hingga kering maka akan berjamur sehingga cost yang dikeluarkan dan pendapatan yang dihasilkan tidak sebanding karena produk sudah rusak terlebih dulu berkat tidak adanya panas matahari untuk 
menjemur. Perlu adanya mesin pengeringan yang digunakan untuk mengeringkan oyek sehingga selain memangkas waktu produksi, tenaga kerja yang dibutuhkan juga semakin efisien.

\subsection{Saran}

Adapun saran yang dapat diberikan bagi kelompok Kadang Tani Milenial dan pemerintah daerah antara lain sebagai berikut.

a. Bagi pemerintah daerah agar lebih menaruh atensi terhadap peluang dari produk-produk olahan industri rumahan yang nantinya bisa dijadikan sebagai salah satu ciri khas dari daerah yang belum dimiliki oleh daerah lainnya sehingga dapat mengangkat citra daerah yang nantinya dapat mendatangkan potensi-potensi lainnya dan mampu meningkatkan pendapatan daerah berkat penjualan produk-produk olahan seperti oyek, madu klanceng, ataupun minuman sarang burung walet. Juga memperhatikan tentang peluang dari industri rumahan seperti yang dilakukan oleh kelompok Kadang Tani Milenial kaitannya dengan sumber daya manusia sehingga seluruh masyarakat terutama yang terdampak pandemi bisa merasakan manfaat dari adanya industri rumahan seperti ini.

b. Bagi kelompok Kadang Tani Milenial untuk bisa menerapkan sistem marketplace dalam memasarkan produk-produk olahan mereka karena potensi yang dimiliki oleh tiap-tiap produk cukup besar. Selain itu, menghimpun pelaku pembuatan produk olahan oyek yang lain untuk dikumpulkan menjadi satu kesatuan agar bisa diberdayakan dan dimaksimalkan potensinya, tidak hanya untuk menyamaratakan harga jual yang beredar, namun juga agar masyarakat yang lainnya juga dapat memasarkan produknya seperti apa yang dilakukan oleh kelompok Kadang Tani Milenial.

\section{DAFTAR PUSTAKA}

[1] Rahayu, A., 2020, Makalah Bahasa Indonesia Pengertian Covid-19 dan Bentuk Partispasi dalam Memeranginya: https://www.researchgate.net/publication/341096752

[2]Anonim, (2020), Memberi wajah Manusia pada Pandemi Covid-19, Majalah Intisari Maret 2020.

[3] RN., P 2020, Indonesia dalam Menghadapi Covid-19, Jurnal Ilmiah Universitas Batanghari, Jambi No. 20 Vol. 2, 705-709: http://ji.unbari.ac.id/index.php/ilmiah/article/view/1010

[4] Safrizal et all., 2020, Pedoman Umum Menghadapi Covid-19, Pencegahan, Pengendalian, Diagnosi dan Manajemen, Tim Kerja Kementerian Dalam Negeri.

[5] H.N., Ulya., 2020, Alternatif Strategi Penanganan Dampak Ekonomi Covid-19 Pemerintah Daerah Jawa Timur pada Kawasan Agropolitan, El-Barca Journal of Islamic Econimic amd $\begin{array}{llllll}\text { Business } & \text { Vol } & 3 & \text { No } & 1, & 80-109:\end{array}$ https://jurnal.iainponorogo.ac.id/index.php/elbarka/article/view/2018

[6] Hermanto, dkk., 2016, Outlook Komoditas Pangan Strategis Tahun 2015-2019, Laporan Analisis Kebijakan Tahun 2016, Pusat Sosial Ekonomi dan Kebijakan Pertanian, Badan Penelitian dan Pengembangan Pertanian

[7] M.A., Budiyanto., 2010, Model Pengembangan Ketahanan Pangan Berbasis Pisang melalui Revitalisasi Nilai Kearifan Lokal, Jurnal Teknik Industri, Vol 11 No 2, 170-177: https://ejournal.umm.ac.id/index.php/industri/article/view/670 
[8] Dewan Riset Nasional, 2006. Agenda Riset Nasional 2006- 2009. Jakarta: DRN

[9] Sutrisno., 2015, Ketersediaan Cabai Merah (Capsicuum annumm. L) dalam Menopang Ketahanan Pangan di Kabupaten Pati, Jurnal Litbang Media Informasi Penelitan Pengembangan dan IPTEK Vol XI No 1, 38-45: https://www.researchgate.net/publication/331953715

[10] N., Prawoto., 2012. Model Pengembangan dan Pemberdayaan Masyarakat Berbasis Kemandirian untuk Mewujudkan Ketahanan Ekonomi dan Ketahanan Pangan (Strategi Pemberdayaan Ekonomi pada Masyarakat Dieng di Provinsi Jawa Tengah), Jurnal $\begin{array}{llllll}\text { Organisasi dan Manajemen } & \text { Vol } 8 \text { No 2, }\end{array}$ http://jurnal.ut.ac.id/index.php/jom/article/view/276

[11] H., Suharyanto., 2011, Ketahanan Pangan, Jurnal Sosial Humaniora Vol 4 No 2, 186-194: http://iptek.its.ac.id/index.php/jsh/article/view/633

[12] A., Abdillah \& A., Zaini., 2018, Analisis Kebutuhan dan Kemampuan Penyediaan Konsumsi Padi di Kabupaten Tana Tidung, Jurnal Pertanian Terpadu Vol 6 No 1, 39-45: http://ojs.stiperkutim.ac.id/index.php/jpt/article/view/141

[13] Hanani AR, Nuhfil, 2008. Ketahanan Pangan, Sumber: http://ajangberkarya. wordpress.com/2008/05/20/pengertian-ketahanan-pangan 